\title{
ANALYSIS OF DRIVING SPEED IN HIGHWAY AND PSYCHOLOGICAL FACTORS IN SPEEDING BEHAVIOR IN THE JAKARTA AREA AND ITS SURROUNDINGS (CASE STUDY: BEKASI MAIN STREET)
}

\author{
Analisis Kecepetan Mengemudi di Jalan Raya dan Faktor Psikologis Yang Berperan \\ Pada Perilaku Ngebut di Wilayah Jakarta dan Sekitarnya \\ (Studi Kasus: Jalan Raya Bekasi)
}

\author{
Guritnaningsih \\ Faculty of Psychology \\ University of Indonesia \\ Kampus Baru UI Depok \\ Depok, West Java \\ gurit_santoso@yahoo.com
}

\author{
Martha Leni Siregar \\ Faculty of Engineering \\ University of Indonesia \\ Kampus Baru UI Depok \\ Depok, West Java \\ leni@eng.ui.ac.id
}

\author{
Ahmad Septiawan \\ Faculty of Engineering \\ University of Indonesia \\ Kampus Baru UI Depok \\ Depok, West Java \\ ahmadseptiawan14@gmail.com
}

\begin{abstract}
Driving a vehicle above the speed limit is unsafe driving behavior that may cause the occurrence of an accident. Speed limitation can be one way to improve road safety. This study aims to get an illustration of speed limit violation committed by the drivers on the national road segment, and also to investigate the demographic and psychological factors that affect driver behavior in violating the speed limit as stated in the traffic regulation. Speed data collection was carried out at the Bekasi Raya national road in Bekasi, while the demographic and psychological data were collected using questionnaires through online methods. The result of speed measurement using Speed Gun to 30 motorcycles, 30 light vehicles, and 30 heavy vehicles, shows that there are no light or heavy vehicles that drive above the speed limit. Speeding behavior only is indicated by a little number of motorcyclists. From the online survey through the distribution of questionnaires to 102 motorcyclists, it was found that speeding behavior tends to be done when they are in a rush situation.
\end{abstract}

Keywords: road safety, driving excess the speed limit, motorcycle, light vehicle, heavy vehicle

\begin{abstract}
Abstrak
Mengendarai kendaraan di atas batas kecepatan (ngebut) merupakan perilaku mengendara yang berkontribusi terhadap terjadinya kecelakaan..Salah satu cara untuk meningkatkan keselamatan di jalan raya adalah dengan pembatasan kecepatan. Penelitian ini bertujuan untuk mendapatkan gambaran tentang pelanggaran batas kecepatan yang dilakukan pengemudi di ruas jalan nasional, dan faktor-faktor demografis, serta faktor psikologis yang berperan dalam perilaku pengendara kendaraan bermotor melanggar batas kecepatan yang telah ditentukan oleh peraturan lalu lintas. Pengambilan data kecepatan dilakukan di jalan nasional Bekasi raya, sedangkan data tentang faktor demografis dan psikologis diperoleh melalui penyebaran kuesioner melalui online. Hasil pengukuran kecepatan terhadap 30 sepeda motor, 30 kendaraan ringan, dan 30 kendaraan berat dengan Speed Gun menunjukkan bahwa tidak ada kendaraan ringan maupun kendaraan berat yang mengemudikan kendaraan di atas batas kecepatan. Perilaku ngebut dilakukan oleh sebagian kecil pengendara sepeda motor. Dari survey melalui penyebaran kuesioner terhadap 102 pengendara diperoleh gambaran bahwa perilaku ngebut cenderung dilakukan ketika berada pada situasi tergesa-gesa.
\end{abstract}

Kata kunci: keselamatan di jalan raya, ngebut, sepeda motor, kendaraan ringan, kendaraan berat

\section{INTRODUCTION}

Road traffic safety is a method and measures that develop to prevent road users from the traffic accident. The program can be in the form of accident prevention and accident 
reduction. In the general provisions of the Minister of Transportation Regulation number 14 in 2006, it is stated that traffic safety is the condition where the road users and the public can be spared from traffic accidents.

One of the main factors that impact the drivers/riders and other road users related to road safety is speed limitation. The purpose of speed limitation is to balance mobility and safety by ensuring a safe and appropriate speed limit for the level of roadside development and road categories (LTSA, 2003).

Without a speed limit, drivers can drive their vehicles with high speed freely (driving at the excess limit). Various studies show that driving above the speed limit is risky and can lead to accidents. According to NHTSA, speeding behavior has a contribution on 30 percent of road accidents. Driving at excess limit behavior is mostly done on the inter cities freeways (Schroeder, Kostyniuk, \&Mack, 2013, in NHTSA report), although in reality, this behavior also happens on inner-city streets, even in residential areas (NHTSA).

In-Law number 22 of 2009 concerning Traffic and Road Transportation, the maximum speed limit is adjusted to residential areas, urban areas, inter-city roads, and highways, while in Government Regulation number 43 of 1993, the maximum speed limit adjusted for road class and type of vehicle. Therefore, the determination of speed limits (maximum and minimum) must pay attention to traffic characteristics, road conditions, and environmental conditions.

In Government Regulation (PP) No. 34 of 2006 concerning roads, it is stated that the authority to roads construction is classified into national roads, provincial roads, district roads, city roads, village roads, and particular roads. Bekasi Raya road is included in the classification of the national highway. The categories which include in national ways are primary arterial roads, primary collector roads that connect between provincial capitals, toll roads, and other roads that have strategic value to the national interest.

According to Svenson, Eriksson, Slovic, Mertz, Fuglestad (2012), the road environment is one of the factors that provoke unsafe driving behavior, such as driving at the excess limit. In Indonesia, where the traffic is crowded, especially in the big cities, it is hard for a fourwheel vehicle to exceed speed limits (speeding). However, it does not mean that there is no speeding behavior. As stated by Svenson et al. (2012), the human factor, which includes demographic and psychological factors that affect unsafe driving behavior. Around 74 percent of accidents are caused by the human factor (Singh, 2015).

\section{Traffic Accident}

An accident is an event that occurs in a traffic movement due to an error in the trafficforming system, namely the driver (human), the vehicle, the road, and the environment. According to Carter \& Hamburger (in Rahman et al., 2004), a traffic accident is an unexpected event that involves at least one motorized vehicle on one road segment and cause material losses and even to the point of death.

\section{Traffic Speed}

Speed is the average distance that can be taken by a vehicle on the road in a particular unit of time (Hobss, 1995). The speed of a vehicle is influenced by human factors, vehicle conditions, infrastructure, traffic flow, weather conditions, and the surrounding natural environment as well. Speed of plan (VR) is the speed of the plan on a road that is chosen as 
the basis of geometric planning that allows vehicles to move safely and comfortably under any conditions. Based on the Geometry Standards of Urban Roads (2004), the design speed (plan) for a road with the same class and function is considered the same along the road segment.

Referring to Government Regulation (PP) Number 79 of 2013, the speed design for each road function is determined as referred to in paragraph (2) and paragraph (3). The speed design for urban areas, as the target of this research, is 50 (fifty) $\mathrm{km} / \mathrm{hour}$ at the highest.

\section{Traffic Volume}

Traffic volume is the number of vehicles that pass the observation point on a particular road segment per unit of time (MKJI, 1997).

\section{Demographic and Psychological Factors}

Among the various demographic factors, age and gender are the factors that contribute to the occurrence of accidents due to driving behavior beyond the speed limit. Young age, between 17 to 35, is more often performing risky driving behavior, including driving at the excess limit, rather than older age. However, it does not mean that the older driver is not driving at the excess limit. As reported in NHTSA, 65 old drivers and older are also driving above the speed limit. Based on gender characteristics, male drivers tend to have riskier driving behavior compared to female drivers. Besides, male drivers are more often to do other types of violations, such as drinking alcohol. Men, in general, have a desire to drive recklessly and need sensation seeking (Chung \& Wong, 2011).

In the field of psychology, the causes of risky driving behavior, including driving beyond the speed limit, can be analyzed by looking at the role of driver's belief, attitude, subjective norms, and Perceived Behavior Control (PBC) (Fishbein \& Ajzen, 1988). Belief is individual knowledge about the consequences of driving above the speed limit. For example, driving at the excess limit can take me to my destination faster. Attitude is someone's evaluation in the sense of like or dislike on driving at excess limit behavior. For example, driving at the excess limit can satisfy my desire to arrive at my destination faster. This attitude has a tight connection with an individual belief about driving at excess limit behavior.

Meanwhile, subjective norms are individual perceptions about the influence of social pressure from significant others to drive beyond the speed limit. For example, my friends push me to drive at the excess limit. The meaning of $\mathrm{PBC}$ is the individual perception of difficulties or easiness to drive at the excess limit. $\mathrm{PBC}$ illustrates someone's experience regarding drive at the excess limit and his/her anticipation of the obstacles that can inhibit him from driving at the excess limit.

\section{METHODS}

\section{For Vehicle Speed Survey}

The research is conducted in one of the national road segments in DKI Jakarta, namely Bekasi Raya road, which is directly adjacent to DKI Jakarta and the city of Bekasi. This study aims to determine the traffic volume and vehicle speed (Motorcycle, Light Vehicle (LV), Heavy Vehicle (HV)). The survey conducted in this study was a Traffic Counting 
Survey and Spot Speed Survey. Data collection for speed survey was using Speed Gun for each of those vehicle classifications: Motorcycle, Light Vehicle (LV), dan Heavy Vehicle (HV). Retrieval of traffic survey data is conducted on Thursday, June 20, 2019, with the total sample for each classification of a vehicle is 30 .

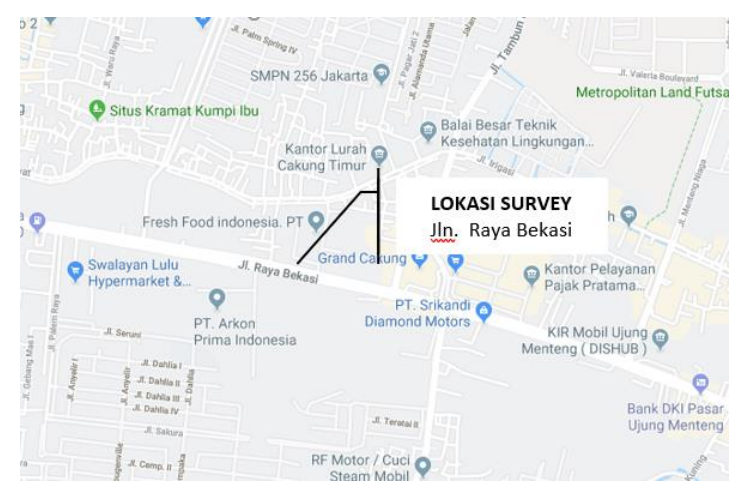

Figure 1. Location of Traffic Counting Survey

Traffic counting survey was conducted using a video recorder for 12 hours, i.e., from 06.00 to 12.00 , and from 15.00 to 21.00 in the evening. Observations were made in Bekasi Raya road for two directions, i.e., from Jakarta to Bekasi, and from Bekasi to Jakarta. Retrieving data from the traffic counting survey is intended to get the Peak Volume Hour (PVH). The calculation was done manually using a hand counter, separately obtained through the results of the recorded video on the day of the survey. Based on the traffic counting result, the analysis was focus on three classifications of vehicles, namely Motorcycle, Light Vehicle (LV), and Heavy Vehicle (HV).

On the other hand, spot speed surveys also conducted to get the mean of the speed of the vehicles on Bekasi Raya road. Data collection was using Speed Gun for each of those vehicle classifications: Motorcycle, Light Vehicle (LV), and Heavy Vehicle (HV). The total sample for each classification is 30 vehicles.

\section{For Demographic and Psychological Factors Survey Concerning Speeding Behavior Participants}

This study is intended for four wheels or more vehicle drivers and motorcycle riders. They are active drivers or riders with a minimum age of 17 and a minimum one-year driving or riding experience. The participants live and ride their vehicles around Jabodetabek areas. These participants were obtained by accidental sampling technique. Through online questionnaire, the researcher got 102 participants within $17-68$ age range (Mean=37.8; $\mathrm{SD}=12.42$ ).

\section{Type of research}

This is quantitative research with a descriptive type of analysis. This type of research is used because this study aims to get a description of belief, attitude, subjective norms, and Perceived Behavior Control (PBC) aspects that underlies speeding behavior.

\section{Data collection instrument}

The information in this study was obtained from three parts of the questionnaires. 1) participant's personal data, consists of gender, age, education, driving license possession, 
driving experience, the most commonly used vehicles, average driving time in a day, experience in getting a traffic ticket, accident experience, and driving at excess limit habit. 2) items about psychological factors, i.e., belief, attitude, subjective norms, and Perceived Behavior Control (PBC) that related to driving at excess limit behavior. Overall, this instrument has good reliability (Cronbach alpha coefficient $=.89$ ). In more detail, reliability score for belief factor $=0.956 ; \mathrm{PBC}=0.815$, attitude factor $=.843$, and subjective norms factor $=.715)$. 3) opinion about driving at excess limit behavior (speeding), which consists of two questions, that is about speed limit application and type of sanctions that need to be given to those who drive at the excess limit on the road.

\section{Data analysis}

Data obtained from the first part of the questionnaire (demographic data) was processed with a descriptive statistic in percentage form. Age and driving experience data were specifically processed using an average score (mean) and standard deviation. Meanwhile, data obtained from the second part of the questionnaire were processed with a descriptive statistic, which is average score (mean) and standard deviation, while data from the third part of the questionnaire were processed with percentage.

\section{RESULTS AND DISCUSSION}

From speed measurements made on the Bekasi Highway, which is a national, urban road, with planned speed (VR) data of $50 \mathrm{~km} / \mathrm{h}$, the following picture is obtained.

Speed survey at Jalan Raya Bekasi which is heading towards Bekasi, it has been recorded that there are frequency of $97.9 \%$ users of motorcycle types (motorcycle), $95.3 \%$ users of Light Vehicle (LV) types of vehicles with speeds of $50 \mathrm{~km} / \mathrm{hour}$, and frequency for (zero) users of Heavy Vehicle (HV) types of vehicles with a speed of $50 \mathrm{~km} / \mathrm{hour}$ during in the morning.

That means, at $2.1 \%$ motorcycle type of vehicle (motorcycle) and $4.7 \%$ Light Vehicle (LV) types of vehicles have speeds above $50 \mathrm{~km} /$ hour (see Figure 2 (a)).

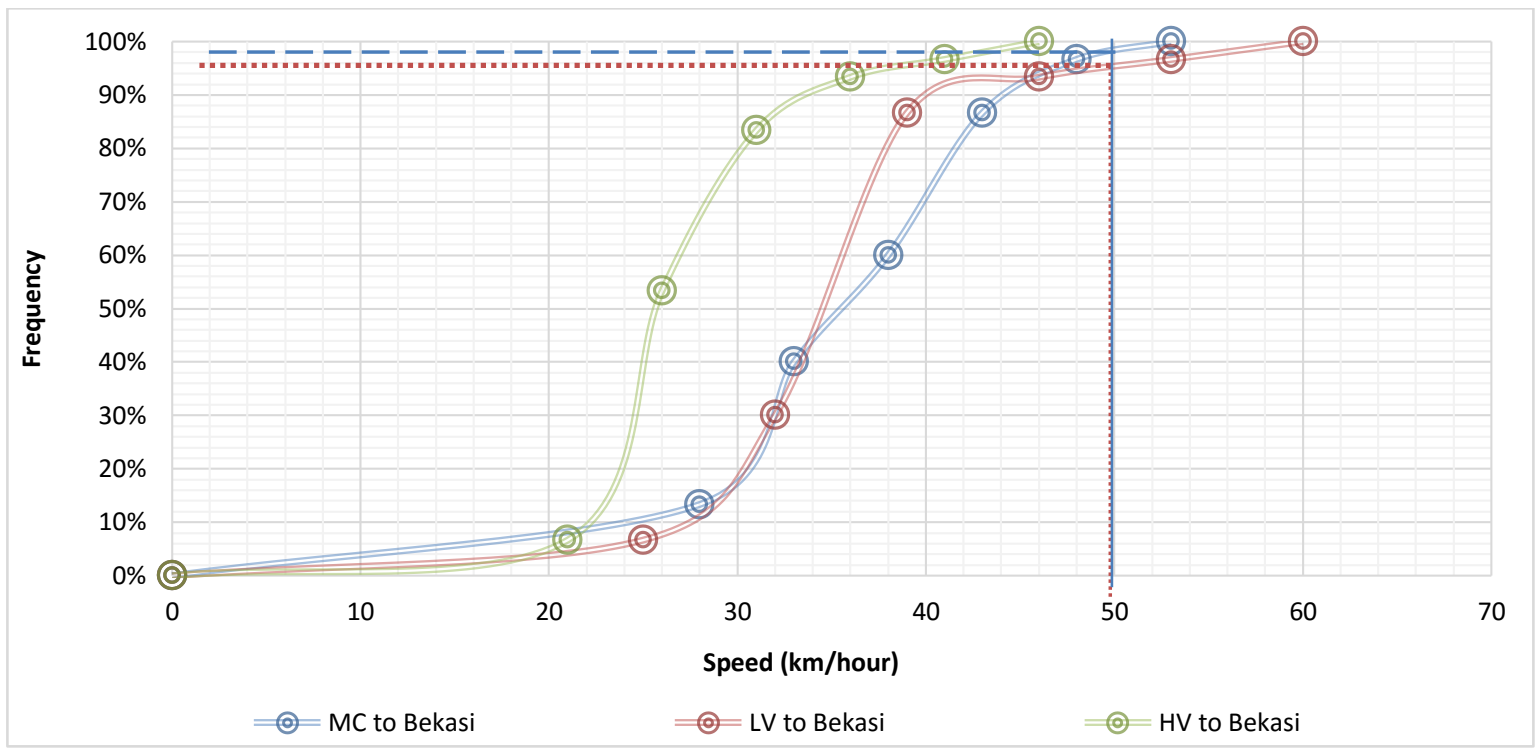

(a) Morning 


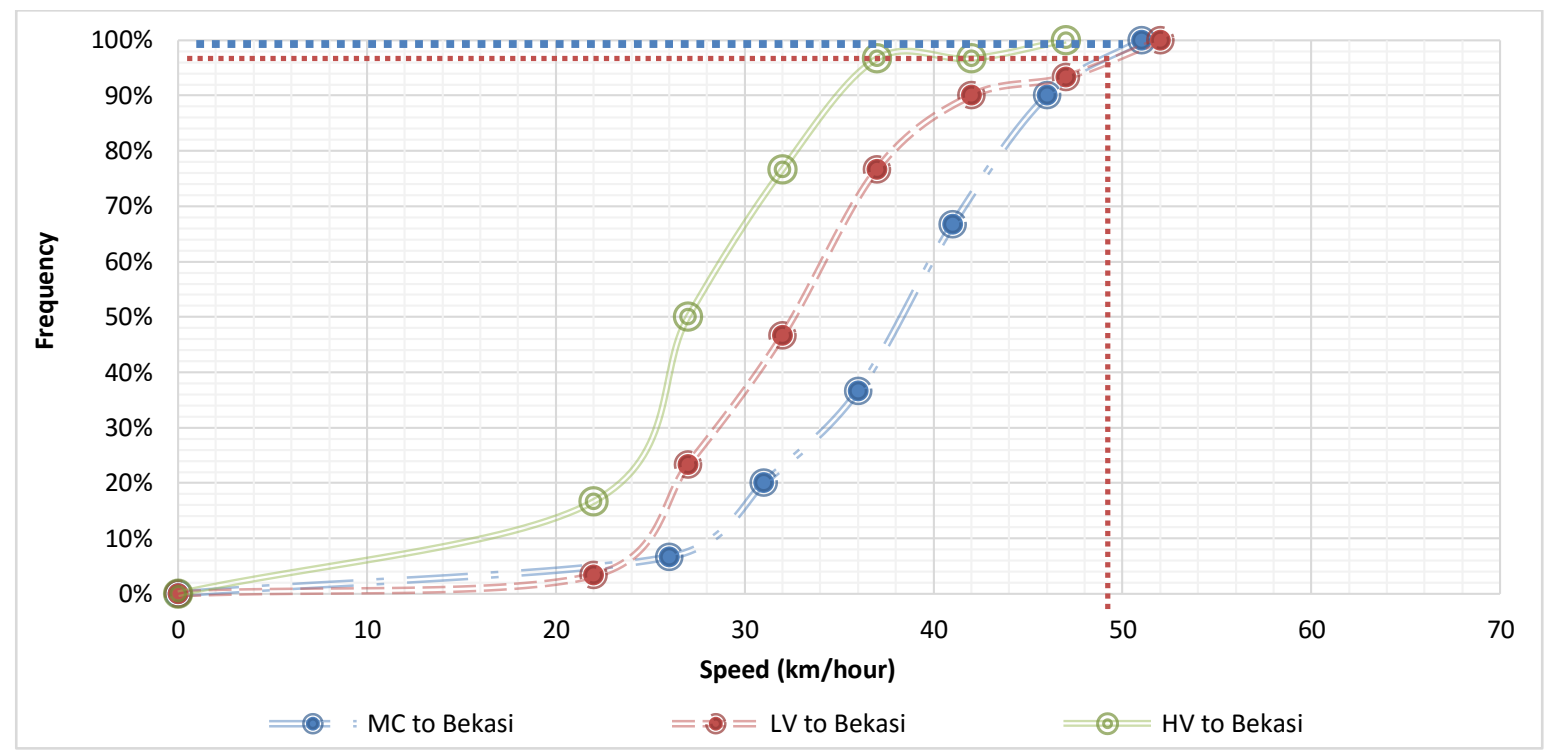

(b) Afternoon

Figure 2. Speed distribution at Jalan Raya Bekasi, direction to Bekasi

Figure 2 (b) shows that the frequencies of vehicles on Jalan Raya Bekasi, which is heading towards Bekasi in the afternoon, are consists of $98 \%$ users of motorcycles and $97.2 \%$ users of Light Vehicle (LV) types with a speed of $50 \mathrm{~km} /$ hour, as well as a frequency of (zero) users Heavy Vehicle (HV) type of vehicle with a speed $50 \mathrm{~km} / \mathrm{hour}$. That means, for the type of motorcycle $2 \%$ vehicles and for the type of Light Vehicle (LV) of $2.8 \%$, vehicles have exceeded the planned speed of $50 \mathrm{~km} /$ hour.

The vehicles which meet the planned speed of $50 \mathrm{~km} /$ hour in the morning are only motorcycle types with a frequency of $95 \%$, which means that the speed of the plan is $5 \%$. None of the types of Light Vehicle (LV) and Heavy Vehicle (HV) that reached speeds of $50 \mathrm{~km} /$ hour in the morning (see Figure 3 (a)).

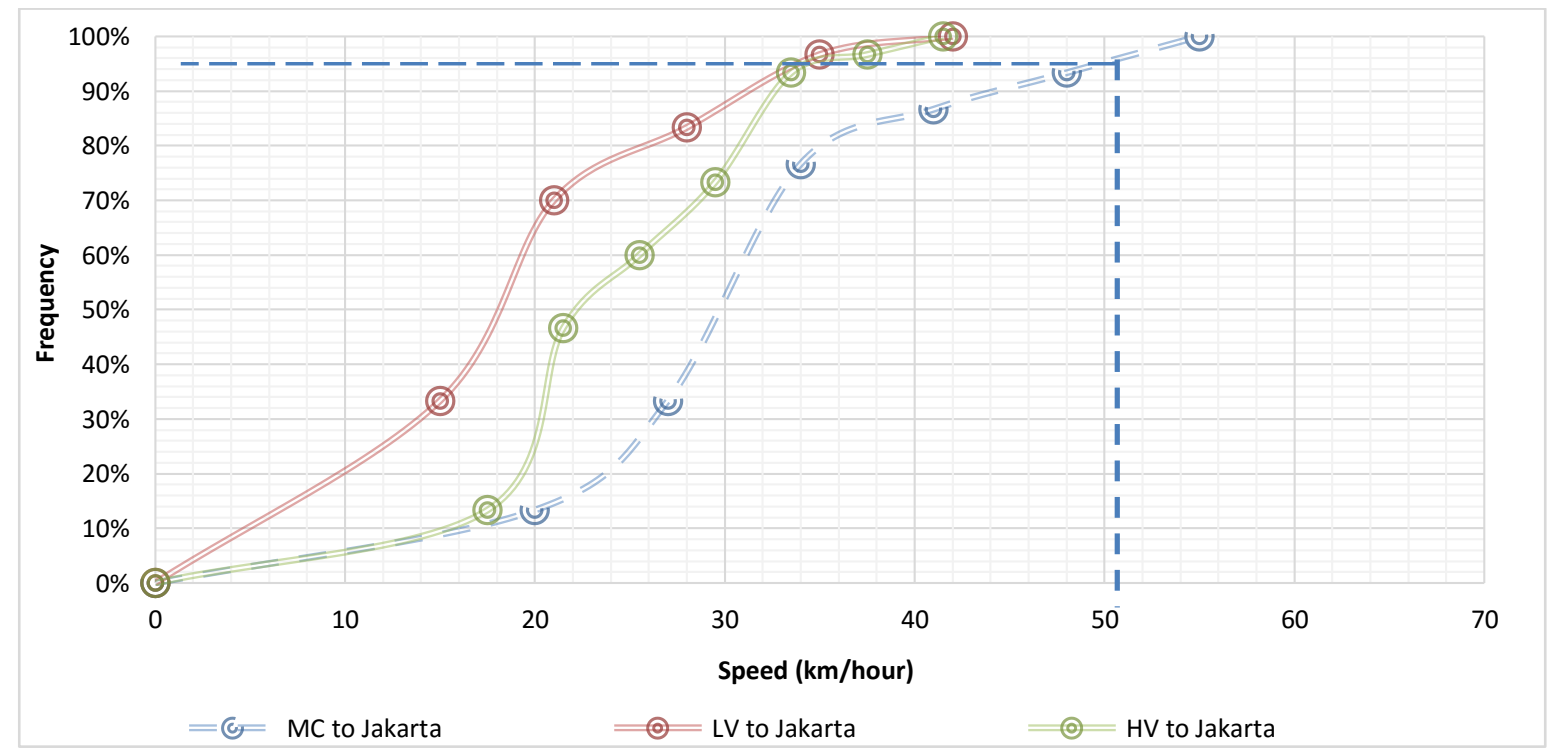

(a) Morning 


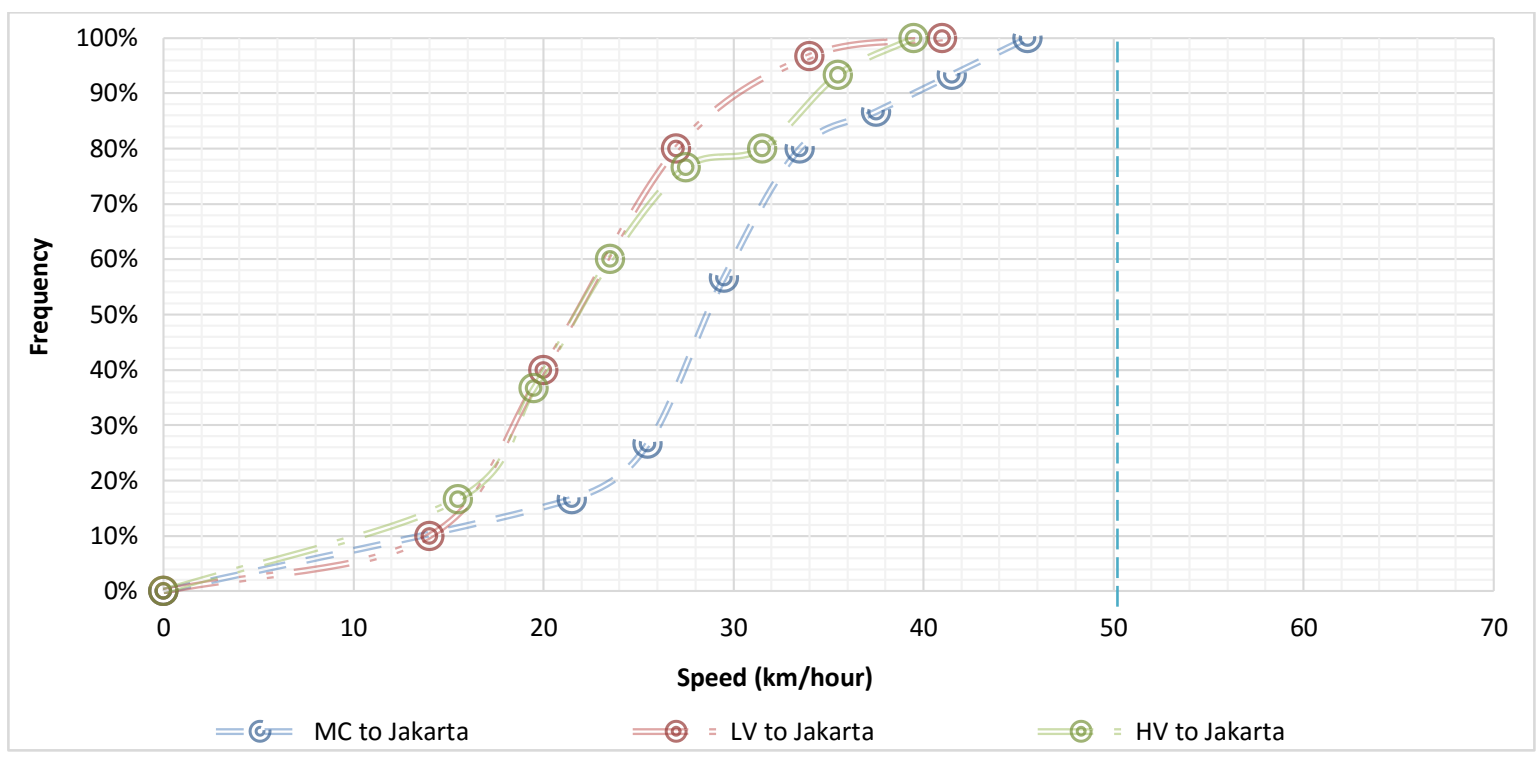

(b) Afternoon

Figure 3. Speed distribution at Jalan Raya Bekasi, direction to Jakarta

In Figure 3 (b), it can be seen that there is no type of vehicle that speeds $50 \mathrm{~km} / \mathrm{hour}$ during the afternoon at Jalan Raya Bekasi in the direction of Jakarta. This shows that the speed in the afternoon is still safe, which is below the minimum plan speed of $50 \mathrm{~km} / \mathrm{hour}$.

\section{Traffic Volume}

In data processing of Traffic Counting on the Jalan Raya Bekasi, the types of vehicles calculated are motorcycles, cars, buses, and trucks. The results of the vehicle volume show that the highest volume on Jalan Raya Bekasi in the direction to Jakarta is between 6.45 too 07.45 in the morning, and between 18.00 to 19.00 in the evening. Whereas in the direction to Bekasi, the highest volume is between 7.15 to 7.45 in the morning, and between 17.15 to 18.00 in the evening.

\section{Speed of 85 Percentile}

Massachusetts Highway Department (2005) states that the main basis for choosing a safe speed for motorists is an understanding of the speed itself. Using the speed of $85^{\text {th }}$ percentile as the basis of submission of speed limits can be applied to take into account the character of the road (road class, alignment, and visibility), segment speed, land use around the road, parking, pedestrian activity, and accident records. Speed of $85^{\text {th }}$ percentile is the speed at or below $85 \%$ in driving. The results of the calculation of the $85^{\text {th }}$ percentile based on field data are as follows. 


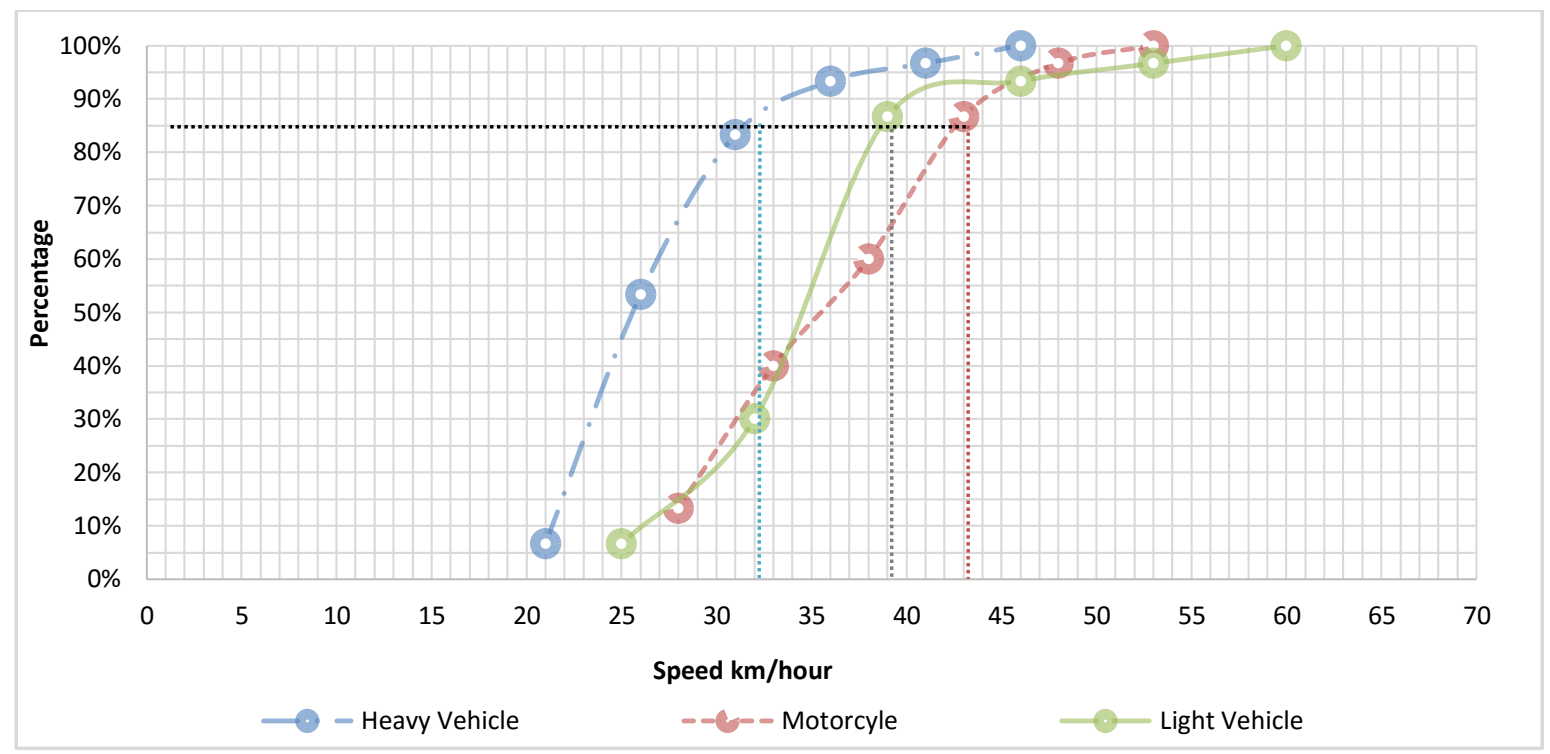

(a) Morning

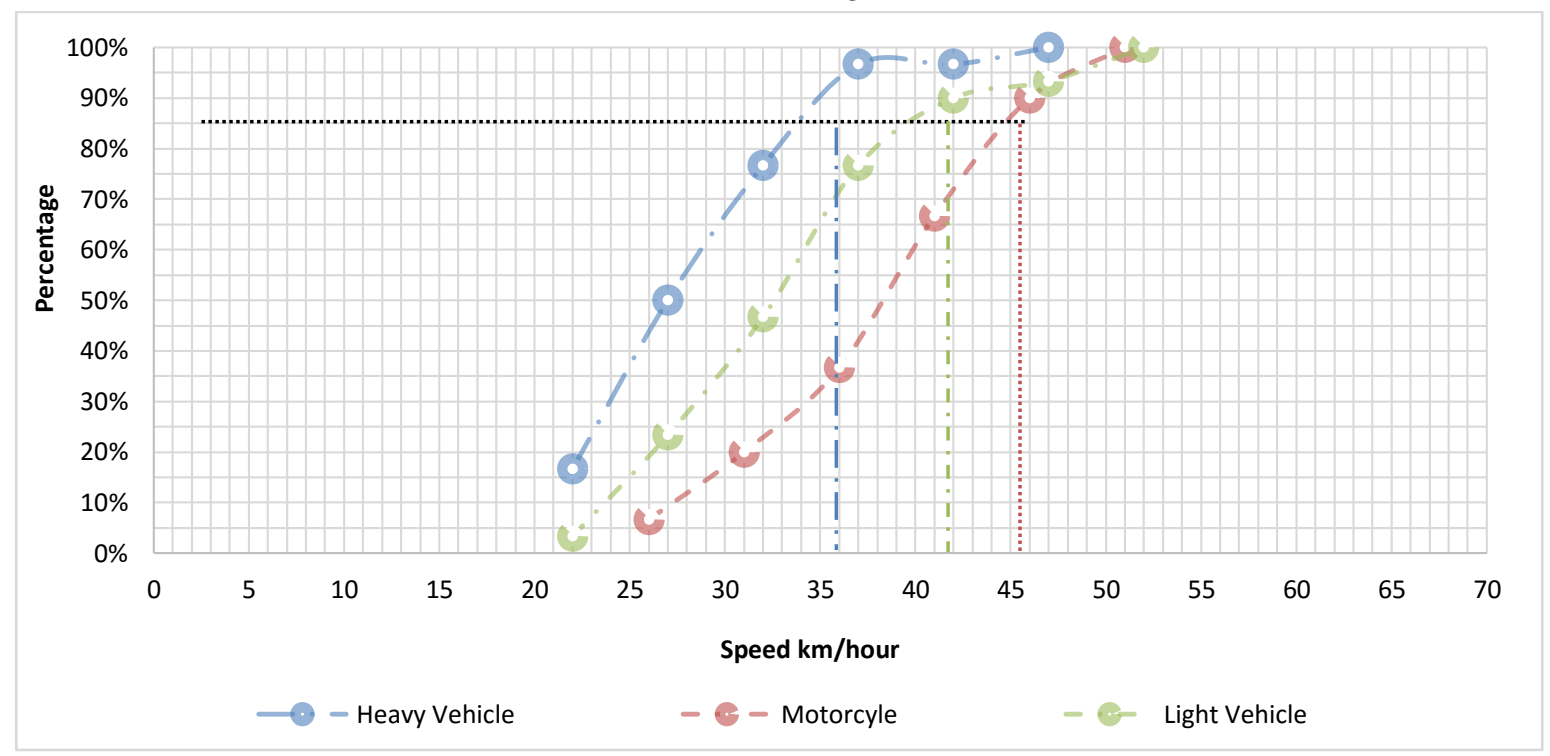

(b) Afternoon

Figure 4. Speed of $85^{\text {th }}$ percentile direction of Bekasi

It can be seen in Figure 4 (a) that \% cumulative speed of 85 on the road for each type of vehicle on Jalan Raya Bekasi for the flow towards Bekasi in the morning are 42.69 $\mathrm{km} / \mathrm{hour}$ for motorcycle, $38.79 \mathrm{~km} /$ hour for Light Vehicle (LV), and $31.83 \mathrm{~km} / \mathrm{hour}$ for Heavy Vehicle (HV).

Figure 4 (b) shows that \% cumulative speed 85 for Jalan Raya Bekasi, which leads towards Bekasi in the afternoon based on the type of motorcycle is $44,9 \mathrm{~km} / \mathrm{hour}$, Heavy Vehicle $34,1 \mathrm{~km} /$ hour and Light Vehicle 40,1 km/hour. 


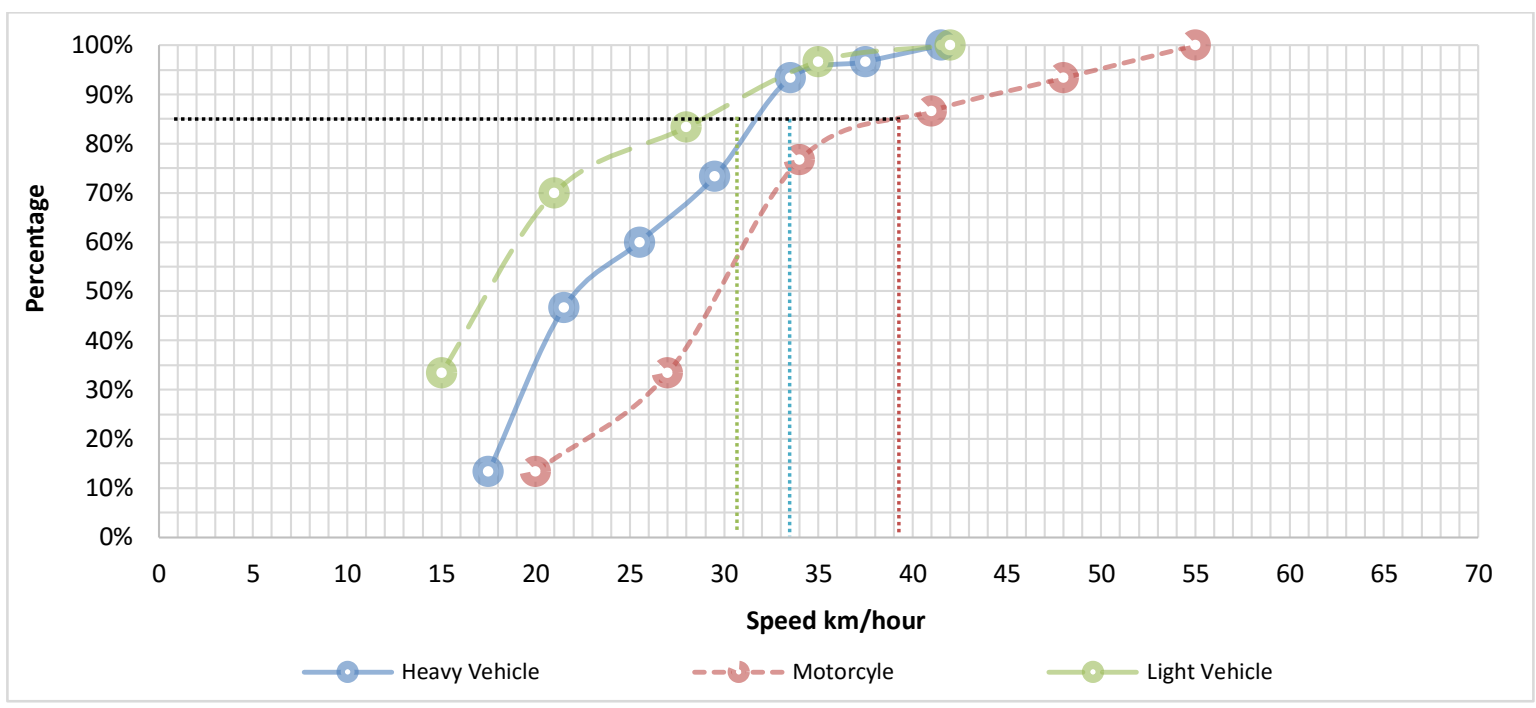

(a) Morning

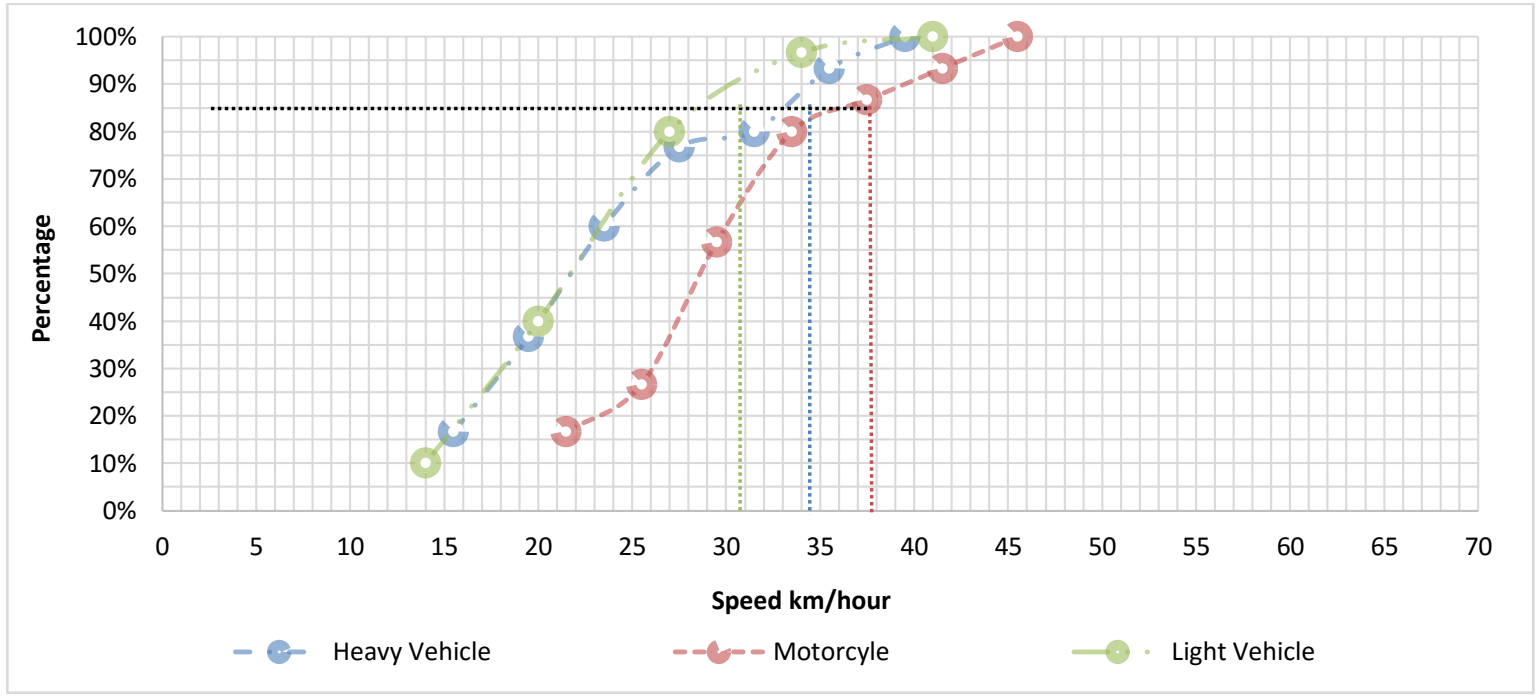

(b) Afternoon

Figure 5. Speed $85^{\text {th }}$ percentile direction to Jakarta

Figure 5 (a) concerning about the cumulative \% speed for each type of vehicle shows that the cumulative \% speed of 85 on Jalan Raya Bekasi for the flow towards Jakarta is 39,83 $\mathrm{km} /$ hour for motorcycle, $38,79 \mathrm{~km} /$ hour for Light Vehicle (LV), and 31,83 km/hour Heavy Vehicle (HV).

Figure 5 (b) shows that for each type of vehicle there is a cumulative $\% 85$ speed on Bekasi Raya road for the flow towards Jakarta in the afternoon; namely, motorcycle is 36,5 $\mathrm{km} /$ hour, Light Vehicle (LV) is $29,1 \mathrm{~km} /$ hour, and Heavy Vehicle (HV) is $33 \mathrm{~km} / \mathrm{hour}$.

\section{Survey of Social Psychological Factor and Driving at Excess Limit Behavior}

\section{The participant's description}

There are more male participants than female participants in this study (63.7\%: 36.3\%). Most of the participants' educational background is a Bachelor's Degree and above (Bachelor Degree - Ph.D.) (79.4\%). (see Table 1). 
Table 1. The description of the participants' personal characteristics $(\mathrm{N}=102)$

\begin{tabular}{cccc}
\hline \multicolumn{2}{c}{ Characteristics } & Frequency & Percentage \\
\hline \multirow{2}{*}{ Gender } & Male & 65 & 63.7 \\
& Female & 37 & 36.3 \\
\hline \multirow{2}{*}{ Education } & High school/equal & 17 & 16.7 \\
& Diploma & 4 & 3.9 \\
& Bachelor & 55 & 53.9 \\
& Master & 24 & 23.5 \\
\hline & PhD & 2 & 2.0 \\
\hline
\end{tabular}

Regarding the type of vehicle, the data shows that more than half of the participants are driving a car (56.9\%), and the rest are riding motorcycles $(43.1 \%)$. They have quite various driving experiences, but most of them have more than ten years of driving experience $(71.6 \%)$, and an only little number of participants who have under three years of driving experience $(3.9 \%)$. All of the participants claim to have a driving license. Most of them have two types of licenses, that is SIM A and SIM C (44.1\%). The majority of the participants said that they never got a traffic ticket $(81.4 \%)$ or had an accident $(88.2 \%)$. However, almost one-fifth of the participants (18.6\%) had got a ticket, and around onetenth of the participants have had an accident (11.7\%). In general, the participants drive/ride their vehicles around 4.42 hours a day $(\mathrm{SD}=9.29)$ in a day.

\section{The psychological factors for speeding}

\section{Belief}

The analysis results show that in regards to their driving/riding vehicle skill, the participants' belief that they have a little possibility to have an accident while driving at the excess limit (Mean=2.13; SD=.69). In detail, the participants generally believe that their driving/riding vehicle skill gives them a low chance to injure other people on the street, injuring a passenger in the vehicle, cause an accident on slippery road, cause an accident on quite road as well as two-way street (Mean range from various answers $=1.99-2.38$ ).

2. Attitude

The participants have a slightly negative attitude towards driving at excess limit behavior (Mean=2.02; $\mathrm{SD}=0.55$ ). They do not feel that driving at excess limits makes them free to express emotion or makes them proud and confident. However, the participants tend to show a positive attitude towards driving at the excess limit because it can satisfy the participants' desire to arrive at their destination faster (Mean= 2.54; $\mathrm{SD}=0.86)$.

3. Subjective norms

This study shows that in the participants' perception, the people around them, such as a friend, family, or police, do not allow or do not support them to drive at the excess limit $($ Mean= 2.04; $\mathrm{SD}=0.51)$. Friend and police are strongly perceived to inhibit driving at excess limit behavior, even on quiet road (not crowded) (friend: Mean=1.8, $\mathrm{SD}=.58$; Police: Mean $=1.85 ; \mathrm{SD}=.81$ ). However, in the participants' perception, the 
police role in inhibiting driving at excess limit behavior is not as strong as their role in checking the completion of vehicle letters (Mean=2.58).

4. Perceived Behavior Control (PBC)

Driving at excess limit behavior is a behavior that under the control of the participants when they want to arrive at the destination fast (Mean=2.76; $\mathrm{SD}=.79)$ and when they want to arrive on time (Mean= 2.73; SD= .73). In other words, the participants are confident to drive at the excess limit when they are in a hurry or do not want to be late at the destination. The participants are insecure about driving at the excess limit to reduce stress, just to test their gut, express anger, run away from the police, show their ability, or to get praises from other people (Mean < 2.00). The result shows the participants' tendency to drive at the excess limit when they feel sleepy.

\section{Driving at excess limit behavior (Speeding)}

Table 2 shows the participants' knowledge about the maximum speed that is recommended in traffic regulations. The participants' knowledge regarding recommended maximum speed in traffic regulations on two-way lanes in the same direction is $60 \mathrm{~km} / \mathrm{hour}$. It can be said that their knowledge is appropriate (Mean= 62.55; $\mathrm{SD}=16.85$ ). However, the participants' knowledge about maximum speed on two lanes two-way street and freeway is higher than the traffic regulations.

Table 2. The participants' knowledge about the maximum speed of the vehicles based on the road types

\begin{tabular}{lcc}
\hline & Mean & SD \\
\hline 2-lanes 2-way street & 49.12 & 16.46 \\
\hline 2-lanes 1-way street & 62.55 & 16.85 \\
\hline Freeway (toll road) & 90.20 & 15.79 \\
\hline
\end{tabular}

Table 3. Speed average when driving at the excess limit

\begin{tabular}{lcc}
\hline & Mean & SD \\
\hline 2-lanes 2-way street & 60.25 & 18.98 \\
\hline 2-lanes 1-way street & 76.13 & 22.82 \\
\hline Freeway (toll road) & 103.92 & 43.12 \\
\hline
\end{tabular}

In reality, the participants tend to drive/ride their motor vehicles above the limits set in the traffic regulations. As seen in Table 3, the participants' average speed on the freeway is above the speed limit set in the traffic regulations. Their speed can over $20-43 \mathrm{~km} / \mathrm{hour}$ above the traffic regulations (Mean $=103.92 ; \mathrm{SD}=43.12$ ).

Three reasons are mentioned by the participants about the importance of speed limit application in Indonesia. The answers that are said by more than 50 percent of participants to reduce accidents $(86.3 \%)$, to be able to handle vehicles when facing a sudden situation $(74.5 \%)$ or unexpected situations, and can minimize fatality if an accident happens $(55.9 \%)$. 
Most of the participants said that the necessary sanctions for those who drive at the excess limit are annulment of driving license forever or jail sentence.

\section{CONCLUSION}

This study shows that on the Jalan Raya Bekasi, both from Jakarta and Bekasi, riding excess the speed limit was done by the motorcycle riders, and none of Light Vehicle (LV) or Heavy Vehicle (HV) reached $50 \mathrm{~km} /$ hour on the morning or the evening (busy hours). The drivers were potentially increasing their speed from 16:00 onwards.

Car drivers are generally had a negative attitude towards driving at excess limit behavior. This attitude is in line with their perception of the people around them who are not supporting them to drive at the excess limit. However, the drivers tend to have a positive attitude toward driving at the excess limit when they are in a hurry situation and want to arrive at their destination on time. This attitude can appear to be a behavior since the riders are generally confident in their ability to drive motor vehicles.

The implication of this study is there is a need for efforts to change the driver's/rider's habit in time management, so they can calculate the time needed on their trip, without having to race to arrive at their destination.

\section{ACKNOWLEDGMENTS}

The data used in this journal are the results of the Transportation Survey founded by Korps Lalu Lintas POLRI (KORLANTAS POLRI) through Traffic Accident Research Center (TARC).

\section{BIBLIOGRAPHY}

Departemen Pekerjaan Umum. (2004). Undang - Undang No. 38 tentang Jalan.

Departemen Pekerjaan Umum. (2006). Peraturan Pemerintah No. 34 tentang Jalan.

Departemen Perhubungan. (2009). Undang - Undang No. 22 tentang Lalu Lintas dan Angkutan Jalan.

Ditjen Bina Marga. (1997). Manual Kapasitas Jalan Indonesia (MKJI). Jakarta: Departemen PU.

Departemen Pekerjaan Umum. (2004). Undang - Undang No. 38 tentang Jalan.

Departemen Pekerjaan Umum. (2006). Peraturan Pemerintah No. 34 tentang Jalan.

Departemen Perhubungan. (2009). Undang - Undang No. 22 tentang Lalu Lintas dan Angkutan Jalan.

Ditjen Bina Marga. (1997). Manual Kapasitas Jalan Indonesia (MKJI). Jakarta: Departemen PU.

Chung Y-S \& Wong, J.T. (2012). Beyond general behavioral theories: Structural discrepancy in young motorcyclist's risky driving behavior and its policy implications. Accident Analysis and Prevention 49 (2012) 165-176

Fishbein, M. and I. Ajzen (1975). Belief; attitude, intention and behavior. AddisonWesley, New York.

Hobbs. (1995). Perencanaan dan Teknik Lalu Lintas. Yogyakarta: Gajah Mada University Press.

LSTA (2003). Dasar-dasar management lalu lintas. 
Massachusetts Highway Department (MHD). (2005). Procedure For Speed Zooning on State and Municipal Roadways. Highway Departmen, Traffic Engineering.

MKJI. (1997). Manual Kapasitas Jalan Indonesia, Direktorat Jenderal Bina Marga. Jakarta: Departemen Pekerjaan Umum.

Pusat Bahasa (2010). Kamus Besar Bahasa Indonesia. Departemen Pendidikan Nasional.

Rahman, A., Subramaniam, Zulkifli, N., \& Hua, T. L. (2005). Car Occupants Accident and Injuries Among Adolescents in A State in Malaysia. Proceeding of the Asia Society for Transportation Studies, Vol. 5, No. 3 : 1867-1874.

Schroeder, P., Kostyniuk, L., \&Mack, M. (2013, December). 2011 National Survey of Speeding Attitudes and Behaviors . (Report No. DOT HS 811 865). Washington, DC: National Highway Traffic Safety Administration. https://rosap.ntl.bts.gov/view/dot/1960, Diunduh pada 4 Juli 2019.

Singh, S. (2015). Critical reasons for crashes investigated in the national motor vehicle crash causation survey Traffic Safety Facts Crash Stats. Washington, DC: National Highway Traffic Safety Administration. 